\title{
CGDENT APPOINTS NEW DCP AMBASSADORS
}

The College of General Dentistry, a new independent college representing the interests of primary care dentistry, has announced the appointment of two Ambassadors who reflect the College's commitment to the whole dental team: Dr Louise Belfield and Dr Marina Harris.

College Ambassadors drawn from different backgrounds will provide strong advocacy for the mission and vision of the College.

More Ambassadors will be appointed in the coming months as the College moves towards its historic, formal launch.

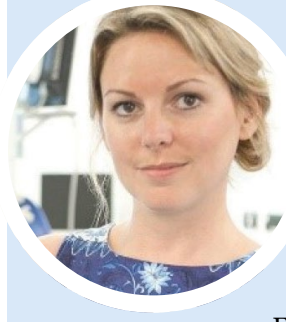

Louise Belfield

Louise Belfield is a dental nurse, research scientist, lecturer, Health Education England Dental Clinical Fellow, and National Examination Board for Dental Nurses (NEBDN) Trustee.

Louise trained as a dental nurse in Devon, qualifying in 2001. She has worked across a range of dental specialties at Torbay and South Devon NHS Foundation Trust including community, special care, and emergency dentistry, and general dental practices across the region. Continuing to practise as a locum dental nurse, Louise gained a BSc (Hons) in Human Biosciences at the University of Plymouth, graduating in 2004, and went on to achieve a doctorate in immunology (2013), and a postgraduate certificate in clinical education (2014). She was awarded Senior Fellowship of the Higher Education Academy in 2019 in recognition of her continued contributions to dental education.

Louise's research focuses on

both the scientific and educational elements required for excellence in evidence informed teaching. In 2017 she co-founded the Oral Microbiome Research Group, as part of which she pursues her specialist interest in how oral bacteria modulate the function of the immune system and can drive oral and systemic diseases such as chronic periodontitis, oral cancer, and hypertension. Since 2017, Louise has led the development and implementation of a Year Zero undergraduate pathway into BSc Dental Hygiene and Therapy, aimed specifically at dental nurses wishing to escalate their skills and widen their scope of practice. Louise is passionate about career development for dental nurses and is a proud advocate for recognition of the profession.

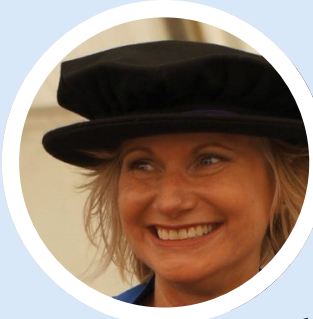

Marina Harris

Marina Harris

has been

involved in dentistry for over 40 years. After training in the RAF as a dental nurse, and then as a dental hygienist, Marina remained in the military for 12 years and then went on to work in a wide variety of primary dental care settings across the UK. Alongside her professional qualifications, Marina has gained an Honours degree from the Open University, a Master's degree from Cardiff Law School, and a Doctorate from the University of Portsmouth.

As a Senior Lecturer since 2002 and a Fellow of the Higher Education Academy, Marina is passionate about advancing research into students and colleagues wellbeing. In addition to her role as teacher and mentor, she has created online wellbeing courses and support tools which she, along with a dentist colleague, delivers on a regular basis.

Driven by a mission to support future clinicians, Marina has always been passionate about widening the opportunities for members of the whole dental team. In addition to her role within undergraduate education of dental hygienists and therapists, she has also played an active role in furthering the education to widen the scope of dental nurses and dental technicians.

Marina is a Past-President of the British Society of Dental Hygiene and Therapy (BSDHT) and has held numerous roles in industry bodies which focus on the advancement of the profession. She is also a regular attender at national and global events as a speaker, organiser, and as an active participant.
Commenting on her appointment Dr Belfield said: 'It is a privilege to become an Ambassador for the College of General Dentistry at a time when teamwork and collegiality are being recognised as paramount in high quality patient care. [...] It is only through working together that we can determine the future of our profession with a united voice.'

Dr Harris said: 'I am honoured to accept the invitation to be an Ambassador for the College of General Dentistry. This is a real opportunity for all members of our great profession to be united as one in the quest to elevate the standing of general dentistry for the good of all.'

TWO-THIRDS OF CHILDREN DID NOT SEE AN NHS DENTIST LAST YEAR

NHS dental attendance figures published in February show that over two-thirds of children (70.2\%) in England did not see an NHS dentist in the 12 months to 31 December 2020.1 The number of children admitted to hospital for tooth decay may rise, if access does not improve this year.

In 2019, over six in ten children under 16 saw a dentist; in 2020, it was less than three in ten.

Mr Matthew Garrett, Dean of the Faculty of Dental Surgery at the Royal College of Surgeons of England, commented: 'While it is not surprising the number of children who saw an NHS dentist dropped so dramatically in 2020 , we must improve access this year to avoid long-term damage to children's teeth'.

\section{Reference}

1. NHS Digital. NHS Dental Statistics for England 2020-2021, Biannual Report. 25 February 2021. Available at: https:// digital.nhs.uk/data-and-information/ publications/statistical/nhs-dentalstatistics/2020-21-biannual-report (accessed 1 March 2021). 